\title{
Problemy psychologiczne pacjentów po implantacji kardiowertera-defibrylatora serca
}

\section{Psychological problems of patients after implantation of a cardioverter-defibrillator}

\author{
Beata Mańkowska-Załuska, Anna Nowek, Ewa Topolska, Andrzej Oszczygieł, \\ Michał Chudzik, Jerzy Krzysztof Wranicz
}

Klinika Elektrokardiologii Katedry Kardiologii i Kardiochirurgii Uniwersytetu Medycznego w Łodzi

\section{Streszczenie}

Od czasu zatwierdzenia przez Agencję ds. Żywności i Leków wszczepialnych kardiowerterów-defibrylatorów (ICD) serca w 1985 roku stały się one metodą z wyboru w zapobieganiu nagłym zgonom sercowym (SCD). W badaniach wykazano, że zastosowanie ICD istotnie zwiększa skuteczność zapobiegania SCD oraz zmniejsza liczbę działań niepożądanych w porównaniu z farmakoterapią. W związku z rozszerzeniem przez Europejskie Towarzystwo Kardiologiczne w 2001 roku wskazań do wszczepiania ICD w ramach profilaktyki pierwotnej znacznie wzrosła liczba osób z tym urządzeniem. Życie pacjentów z wszczepionym ICD ulega zmianie i wiele z nich (do 87\%) odczuwa niepokój związany z działaniem urządzenia. W badaniach dowiedziono, że czynnikami predysponującymi do zaburzeń psychicznych pojawiających się po wszczepieniu ICD są: wiek poniżej 50. roku życia, płeć żeńska, brak wsparcia społecznego i rodzinnego, liczne wyładowania urządzenia. Pacjenci powinni być świadomi działania urządzenia ICD oraz uczestniczyć w terapiach i grupach wsparcia, które pomogą im opanować negatywne emocje tj. lęk, niepokój i stres związane z wszczepionym urządzeniem. Należy pamiętać, że od dobrostanu psychicznego pacjenta zależy pełen sukces terapeutyczny po wszczepieniu ICD.

Słowa kluczowe: wszczepialny kardiowerter-defibrylator, niepokój, zaburzenia psychiczne, wyładowanie ICD, stres

(Folia Cardiologica 2015; 10, 5: 342-347)

\section{Wstęp}

Od czasu zatwierdzenia przez amerykańską Agencję ds. Żywności i Leków (FDA, Food and Drug Administration) wszczepialnych kardiowerterów-defibrylatorów (ICD, implantable cardioverter-defibrillators) serca w 1985 roku stały się one metodą z wyboru w zapobieganiu nagłym zgonom sercowym (SCD, sudden cardiac death). Autorzy licznych prac dowodzą większej skuteczności ICD w zapobieganiu SCD w porównaniu z lekami antyarytmicznymi [1, 2]. Jednoroczna śmiertelność wynosiła 2-5\% u pacjentów z ICD w porównaniu z 10-40\% u pacjentów poddanych terapii wyłącznie lekami antyarytmicznymi [3]. Leczenie za pomocą ICD prowadzi do obniżenia względnego ryzyka zgonu o $23 \%$ oraz o $7,2 \%$ bezwzględnego ryzyka zgonu w obserwacji 5 letniej [1]. Z kolei w badaniu MADIT-II (Multicenter Automatic Defibrillator Implantation Trial II) wykazano, że zastosowanie ICD obniżyło o 31\% względne ryzyko zgonu, głównie w wyniku 57-procentowej redukcji ryzyka zgonów z przyczyn arytmicznych [2]. Skuteczność działania ICD w zapobieganiu SCD potwierdzono w licznych badaniach - zarówno wśród pacjentów, u których implantowano ICD w ramach profilaktyki pierwotnej, jak i wtórnej. Do implantacji ICD, zgodnie z aktualnymi wytycznymi European Society

Adres do korespondencji: mgr Beata Mańkowska-Załuska, Klinika Elektrokardiologii, Katedra Kardiologii i Kardiochirurgii,

Uniwersytet Medyczny w Łodzi, ul. Pomorska 251, 92-213 Łódź, e-mail: b.mankowska.zaluska@gmail.com 
of Cardiology (ESC) z 2012 roku, są kwalifikowani chorzy po przebytym incydencie nagłego zatrzymania krążenia w mechanizmie migotania komór lub częstoskurczu komorowego, jak również chorzy po incydencie utrwalonego częstoskurczu komorowego powodującego niestabilność hemodynamiczną w ramach profilaktyki wtórnej. Drugą grupę stanowią chorzy kwalifikowani do implantacji ICD w ramach tak zwanej profilaktyki pierwotnej, czyli chorzy obciążeni wysokim ryzykiem wystąpienia groźnej dla życia arytmii komorowej, z niską frakcją wyrzutową ( $\leq 35 \%)$, niewydolnością serca w II klasie według New York Heart Association (NYHA) lub wyższej, optymalnie leczeni farmakologicznie.

Działanie tego urządzenia może zwiększać uczucie lęku i niepokoju, zwłaszcza wśród osób, które doświadczyły wysokoenergetycznej terapii urządzenia. W licznych pracach opisano zaburzenia depresyjne i lękowe u chorych po wyładowaniu ICD [4-6]. Od 10\% do 39\% pacjentów, u których implantowano urządzenie w ramach profilaktyki pierwotnej, doznało wyładowania ICD w pierwszym roku po implantacji $[7,8]$. Pacjenci z ICD mogą doświadczyć wyładowań adekwatnych w przebiegu arytmii komorowej lub wyładowań nieadekwatnych w przebiegu arytmii nadkomorowej, szumów elektromagnetycznych lub tak zwanych trzasków wywołanych uszkodzeniem elektrody, błędnie rozpoznanych przez urządzenie jako arytmia komorowa. W ciągu 2 lat od implantacji aż 50-70\% pacjentów doznało adekwatnego wyładowania defibrylatora $[9,10]$, ponadto 10-30\% pacjentów doznało epizodu burzy elektrycznej, czyli co najmniej 3 epizodów częstoskurczu komorowego lub migotania komór w ciągu doby wymagających interwencji ICD [11, 12]. Co więcej, nawet 11-15\% pacjentów [13-15] z ICD doświadczyło nieadekwatnych terapii urządzenia. Migotanie przedsionków jest najczęstszą przyczyną nieadekwatnych wyładowań (44\%); wśród innych przyczyn należy wymienić częstoskurcz nadkomorowy (36\%) i nieprawidłowe wyczuwanie sygnału przez elektrodę (20\%) [15].

W przebiegu burzy elektrycznej dochodzi do licznych interwencji ICD - nisko- (ATP, antitachycardia pacing) i/lub wysokoenergetycznych. Choć pojęcie to ogranicza się jedynie do wyładowań adekwatnych, czyli w przebiegu tachyarytmii komorowych, to często termin ten pojawia się również w języku potocznym w odniesieniu do pacjentów, u których wystąpiły liczne nieadekwatne wyładowania. Częste wyładowania, bez względu na ich typ - adekwatne czy nieadekwatne - są przyczyną zaburzeń lękowo-depresyjnych przypominających zespół stresu pourazowego (PTSD, posttraumatic stress disorder) [11]. Zespół ten rozpoznaje się, gdy pacjent wskutek silnego stresu spowodowanego wyładowaniem znajduje się w stanie odrętwienia psychicznego, wciąż wraca do momentu, w którym wystąpiło wyładowanie oraz unika bodźców, które mu się z nim kojarzą. Objawy te powodują dystres prowadzący do zaburzenia życia społecznego i zawodowego. Zespół stresu pourazowego rozpoznaje się, gdy stan odrętwienia utrzymuje się u pacjenta przez co najmniej miesiąc [16]. Badania służące ocenie dobrostanu psychicznego chorych z ICD wskazują, że 24-87\% pacjentów odczuwała niepokój związany z wszczepionym urządzeniem [17]. Aż 13-38\% pacjentów wymagało terapii psychologicznej i psychiatrycznej z powodu stanów lękowych, a 24-33\% pacjentów miało objawy depresji [17]. Jedenaście procent pacjentów (11\%) uważało, że korzyści płynące z implantacji ICD nie przewyższały negatywnych odczuć, a ból towarzyszący wyładowaniu był wręcz „nie do zniesienia” [18]. Nawet 5\% pacjentów nie wyraziłoby zgody na implantację ICD, mając możliwość ponownego wyboru [18]. Liczne wyładowania mogą również prowadzić do zespołu agorafobii, czyli paniki w miejscach i sytuacjach, które kojarzą się bezpośrednio z wyładowaniem ICD. Zespół agorafobii dotyczy blisko 16\% chorych z wszczepionym ICD [19]. Problem lęku przed wyładowaniami przejawia się również odczuwaniem bólów fantomowych, czyli związanych z wyładowaniami ICD, które w rzeczywistości nie nastąpiły. Wśród pacjentów z ICD ważną rolę odgrywa edukacja zdrowotna. W badaniu Dunbar i wsp. [20] wykazano, że pacjenci, którym zapewniono pomoc psychologiczną, odczuwali mniejszy niepokój i rzadziej występowały u nich zaburzenia depresyjne. Odpowiednie podejście lekarza do pacjenta zmniejsza niepokój i lęk związany z działaniem ICD. Dowiedziono, że nawet w sytuacji, gdy ICD działa nieprawidłowo, można ograniczyć negatywny wpływ stresującego zdarzenia na jakość życia pacjenta dzięki właściwie przeprowadzonej z nim rozmowie przez lekarza [21].

Wiele psychologicznych modeli wyjaśnia sposób i uwarunkowania powstawania zaburzeń psychicznych u pacjentów z ICD. Pacjenci, którzy doznali wyładowania ICD, unikają bodźca bezpośrednio kojarzącego się im z tym zdarzeniem. Reakcję tę wyjaśnia model warunkowania klasycznego (classic conditioning model pairs) oznaczający formę uczenia się polegającą na tym, że zachowanie (reakcja warunkowa) zaczyna być wywoływane przez pewien bodziec (bodziec warunkowy), który uzyskał tę zdolność wskutek powiązania go z bodźcem istotnym biologicznie (bodźcem bezwarunkowym) [4]. Teoria wyuczonej bezradności tłumaczy zachowanie pacjentów po licznych wyładowaniach ICD, którzy czują się bezsilni, nie mogąc w żaden sposób im zapobiec, w wyniku czego odczuwają bezsens i depresję [4]. Według modelu ocen poznawczych (cognitive apprisal model) pacjent odbiera sygnały w postaci wyładowań urządzenia jako wyraz pogorszenia stanu zdrowia. U niektórych pojawiają się wtedy myśli o nadchodzącej śmierci (tzw. myślenie katastroficzne). Te subiektywne odczucia prowadzą do rozwoju zaburzeń psychicznych, między innymi depresji lub stanów lękowych [4]. Według strategii radzenia sobie ze stresem niektórzy pacjenci, ze względu na przewlekły stres związany z ICD, nie są w stanie się uporać ze stresem wywołanym codziennym życiem, w tym aktywnościami zawodowymi czy społecznymi [22]. 
Fricchione i wsp. [23] wyróżnili cztery główne reakcje psychologiczne pacjenta po wszczepieniu ICD. Pierwsza przypomina zespół lęku napadowego z agorafobią i polega na unikaniu wychodzenia z domu z obawy przed kolejnym wyładowaniem w miejscu publicznym. Druga reakcja zawiera elementy modelu oceny poznawczej i strategii radzenia sobie ze stresem związanym z wyładowaniem ICD i polega na podejmowaniu przez pacjenta jedynie tych aktywności, które według niego nie powodują wyładowania ICD, w wyniku czego pacjent całkowicie uzależnia swoje życie od wszczepionego urządzenia. Trzecia reakcja, z kolei, polega na traktowaniu ICD jak własnego „anioła stróża” zapewniającego poczucie bezwzględnego bezpieczeństwa i niezniszczalności. Ostatnia reakcja pojawia się po usunięciu ICD - wtedy pacjent odczuwa silny lęk z powodu utraty poczucia bezpieczeństwa (tzw. safety net), jaką dawało mu urządzenie.

\section{Uwarunkowania zaburzeń psychicznych u pacjenta $z$ ICD}

W badaniach są opisywane cztery główne rodzaje uwarunkowań wystąpienia zaburzeń psychicznych u pacjenta z ICD:

- demograficzne;

- osobowościowe;

- środowiskowe;

- spowodowane wyładowaniem ICD.

\section{Czynniki demograficzne}

Do czynników demograficznych wpływających na częstość wystąpienia zaburzeń psychicznych wśród chorych z ICD należą wiek i płeć. Pacjenci poniżej 50. roku życia są bardziej narażeni na pojawienie się zaburzeń lękowo-depresyjnych, ponadto mają większe trudności w radzeniu sobie ze stresem wywołanym wyładowaniem ICD [23]. Opisano liczne problemy zgłaszane przez 9-letniego chłopca i jego matke, takie jak: lęk przed wyładowaniem, ograniczanie i unikanie aktywności fizycznej, lęk przed chodzeniem do szkoły, trudności ze snem oraz pojawienie się natrętnych zachowań [24]. Młodsi pacjenci obawiają się aktywności fizycznej lub podejmowania aktywności seksualnej, a ponadto czują się mniej atrakcyjni z powodu blizny po implantacji ICD. W amerykańskim badaniu NSIRSO (A US national survey of ICD patients and spouses) wśród pacjentów z ICD i ich współmałżonków odnotowano, że kobiety poniżej 50. roku życia, które doświadczyły licznych wyładowań ICD, miały istotnie większe trudności w adaptacji do nowej sytuacji będącej następstwem uporczywej terapii ICD [35].

\section{Czynniki osobowościowe}

Osobowość typu D charakteryzuje się tendencją do odczuwania negatywnych emocji, tj. lęku, gniewu, irytacji oraz zahamowań społecznych polegających na unikaniu zagrożenia związanego z relacjami społecznymi. Pacjenci z osobowością typu D wykazywali większą skłonność do odczuwania niepokoju i depresji po implantacji ICD [25]. Typ D osobowości i niższa ocena jakości życia (QoL, quality of life) uwarunkowanej stanem zdrowia wiązały się ze zwiększonym ryzykiem śmiertelności u pacjentów z ICD [26]. Dowiedziono, że zaburzenia lękowe i somatyczne u chorych z ICD są związane z niższą oceną QoL [27].

\section{Czynniki środowiskowe}

Zarówno nadmierne zaangażowanie otoczenia przejawiające się nadwrażliwością emocjonalną i nadopiekuńczością, jak i niedostateczne zainteresowanie czy uczucie osamotnienia są skorelowane z występowaniem psychopatologii u osób z ICD. Brak wsparcia społecznego i złe relacje rodzinne miały nawet większy wpływ na rozwój depresji i lęku niż liczne wyładowania ICD [28]. Osoby mieszkające samotnie, w młodszym wieku, po zawale i z niewydolnością serca cechowało większe prawdopodobieństwo rozwoju zaburzeń lękowo-depresyjnych [29].

\section{Wyładowania ICD}

W większości badań odnotowano niższą QoL u osób, u których wystąpiły wyładowania ICD [4]. Istotność statystyczna tej zależności zwiększa się wraz z liczbą wyładowań ICD. W badaniu kanadyjskiej grupy 317 pacjentów dowiedziono, że wyższa QoL cechowała pacjentów po implantacji ICD niż leczonych amiodaronem, jeśli nie doznawali więcej niż 5 wyładowań w ciągu 12 miesięcy [30]. Schron i wsp. [8] wykazali, że nawet sporadyczne wyładowanie było związane z obniżeniem QoL - zarówno w wymiarze psychicznym, jak i fizycznym - oraz zwiększeniem poziomu niepokoju wśród osób z ICD.

\section{Leczenie zaburzeń psychicznych u osób z ICD}

Jedną z form terapii pacjentów po implantacji ICD jest terapia poznawczo-behawioralna (CBT, cognitive behavioral therapy), która polega na interpretacji zdarzeń wywołujących negatywne uczucia. Jej celem jest zmiana sposobu myślenia („poznawczość”) i zachowania („behawioryzm”), co przyczynia się do poprawy samopoczucia. W badaniu wykazano, że po 9 miesiącach obserwacji pacjenci uczestniczący w CBT mieli mniej zaburzeń depresyjnych, odczuwali mniejszy niepokój i mieli mniej problemów w życiu seksualnym niż pacjenci nieuczestniczący w terapii [31]. Aż 96\% pacjentów z ICD i ich opiekunów uczestniczących w tak zwanych grupach wsparcia uważało ten sposób terapii za bardzo pomocny [30]. Celem grup jest zwiększenie poziomu świadomości pacjentów na temat działania urządzenia oraz przekazanie sposobów radzenia sobie ze stresem związanym z ICD. Większość pacjentów (91\%) potrzebowała wsparcia w dostosowaniu się do życia z urządzeniem ICD. Ponad $83 \%$ było zdania, że edukacja dotycząca działania 
ICD była efektywną formą zapobiegania zaburzeniom lękowo-depresyjnym [32]. Osoby uczestniczące w grupach wsparcia zgłaszały lepszy stan zdrowia niż przed implantacją ICD ( $p=0,03 ; r=0,31)$, wykazywały większą chęć do pracy $(p=0,03 ; r=0,31)$ i większe zainteresowanie życiem towarzyskim $(p=0,01 ; r=0,36)[30]$.

\section{Wpływ ICD na QoL}

W amerykańskim badaniu NSIRSO u 91\% pacjentów z ICD odnotowano zadowalający poziom QoL, w tym u 45\% nastąpiła poprawa, a u 46\% QoL nie uległa zmianie w stosunku do oceny przed implantacją ICD [33]. W badaniu PainFREE Rx II (Pacing Fast VT REduces Shock ThErapies) wykazano, że ocena QoL nie zależy od wskazania do zabiegu i w obu grupach osób, którym implantowano urządzenie ICD - zarówno w ramach profilaktyki pierwotnej, jaki i wtórnej, nastąpiła umiarkowana poprawa QoL po 12 miesiącach obserwacji [13]. W innych badaniach również nie udowodniono różnic w ocenie QoL wśród pacjentów poddanych implantacji ICD w ramach profilaktyki pierwotnej w porównaniu z profilaktyką wtórną (tab. 1) [13, 34-39]. Wśród czynników predysponujących do niższej QoL u osób z wszczepionym ICD są: wiek (osoby < 50. rż. gorzej oceniają QoL) [40], płeć żeńska [41], liczne choroby współistniejące [42], licz- ba wyładowań ICD. Ponadto do niższej QoL predysponują niedostateczne wsparcie społeczne w otoczeniu pacjenta [43], nieumiejętność radzenia sobie ze stresem [44] oraz brak akceptacji przez pacjenta wszczepionego urządzenia [43]. W badaniu służącym ocenie QoL wykazano brak różnic w tym zakresie między pacjentami z zaimplantowanym ICD w ramach profilaktyki pierwotnej a osobami bez urządzenia. Różnica w QoL pojawiła się dopiero po wystąpieniu wyładowania ICD, które istotnie ją obniżyło u pacjentów zarówno w sferze fizycznej, jaki i psychicznej [45].

\section{Wnioski}

Z roku na rok zwiększa się liczba pacjentów z wszczepionym ICD. Nawet 38\% z nich wymaga pomocy psychologicznej i psychiatrycznej. Najsilniejszym czynnikiem budzącym lęk są terapie wysokoenergetyczne ICD. Liczne wyładowania to istotny czynnik negatywnie wpływający na występowanie zaburzeń psychicznych i obniżenie QoL pacjenta. Niezwykle ważnym problemem jest właściwa informacja, jaką każdy pacjent powinien otrzymać od lekarza oraz pielęgniarki po implantacji ICD o metodach terapii stosowanych przez urządzenie. Chorzy świadomi działania urządzenia łatwiej tolerują ból i odczuwają mniejszy niepokój w przypadku, gdy ICD podejmie terapię wysokoenergetyczną. Chorzy po

Tabela 1. Przegląd badań dotyczących zależności między wskazaniami klinicznymi (profilaktyka pierwotna lub wtórna) do implantacji wszczepialnego kardiowertera-defibrylatora (ICD, implantable cardioverter-defibrillator) a oceną jakości życia (QoL, quality of life) (źródła [13, 34-39])

\begin{tabular}{|c|c|c|c|c|c|c|}
\hline Autorzy & $\begin{array}{c}\text { Liczba } \\
\text { pacjentów } \\
\text { badaniu }\end{array}$ & $\begin{array}{c}\text { Rodzaj } \\
\text { badania }\end{array}$ & Kwestionariusz & $\begin{array}{l}\text { Kwestiona- } \\
\text { riusz swoisty } \\
\text { dla choroby }\end{array}$ & $\begin{array}{l}\text { Punkty końcowe } \\
\text { badania }\end{array}$ & $\begin{array}{l}\text { Ocena zależności } \\
\text { między wskazaniami } \\
\text { klinicznymi a QoL }\end{array}$ \\
\hline $\begin{array}{l}\text { Bilge i wsp. } \\
\text { [34] }\end{array}$ & 91 & Przekrojowe & HADS & Nie & Niepokój, depresja & Brak zależności \\
\hline $\begin{array}{l}\text { Groeneveld } \\
\text { i wsp. [35] }\end{array}$ & 120 & Przekrojowe & $\begin{array}{c}\text { Euro-QoL, SF-12, } \\
\text { Health Utilities } \\
\text { Index-Mark, FPAS, } \\
\text { Essential ICD QoL } \\
\text { Domains }\end{array}$ & Tak & $\begin{array}{l}\text { Ocena ogólnej QoL } \\
\text { i jakości życia u cho- } \\
\text { rych z ICD }\end{array}$ & Brak zależności \\
\hline $\begin{array}{l}\text { Pedersen } \\
\text { i wsp. [36] }\end{array}$ & 154 & Prospektywne & SF-36 & $\mathrm{Nie}$ & Ocena ogólnej QoL & Brak zależności \\
\hline $\begin{array}{l}\text { Pedersen } \\
\text { i wsp. [37] }\end{array}$ & 176 & Prospektywne & HADS & $\mathrm{Nie}$ & Niepokój, depresja & Brak zależności \\
\hline $\begin{array}{l}\text { Sweeney } \\
\text { i wsp. [13] }\end{array}$ & 426 & $\begin{array}{l}\text { Randomizowa- } \\
\text { ne, kontrolowa- } \\
\text { ne badanie }\end{array}$ & SF-36 & $\mathrm{Nie}$ & Ocena ogólnej QoL & Brak zależności \\
\hline $\begin{array}{l}\text { Van den Broek } \\
\text { i wsp. [38] }\end{array}$ & 308 & Prospektywne & STAI, HAM-A & $\mathrm{Nie}$ & Niepokój & Brak zależności \\
\hline $\begin{array}{l}\text { Van den Broek } \\
\text { i wsp. [39] }\end{array}$ & 165 & Prospektywne & HCS, ICDC2, HAM-A & Tak & $\begin{array}{l}\text { Poczucie niepełno- } \\
\text { sprawności, objawy } \\
\text { niewydolności krąże- } \\
\text { nia, niepokój, dolegli- } \\
\text { wości związane z ICD }\end{array}$ & Brak zależności \\
\hline
\end{tabular}

HADS - Hospital Anxiety and Depression Scale; SF-12 - Short Form Health Survey 12; FPAS - Florida Patient Acceptance Survey; SF-36 - Short Form Health Survey 36; STAI - Spielberger State-Trait Anxiety Index; HAM-A - Hamilton Rating Scale for Anxiety; HCS - Health Complaints Scale; ICDC - ICD Concerns questionnaire 
pierwszym w życiu wyładowaniu powinni mieć możliwość kontaktu z lekarzem, aby ten mógł wyjaśnić przyczynę wyładowania i przedstawić jej pozytywne dla chorego strony. Ponieważ na sukces terapeutyczny składa się również stopień psychicznego dobrostanu, pacjenci powinni móc uczestniczyć w terapiach i grupach wsparcia, które pomogą opanować negatywne emocje, lęk, niepokój i stres związany z wszczepionym urządzeniem. Wszyscy pacjenci po epizodzie burzy elektrycznej, poza sprawdzeniem urządzenia przez lekarza i uzyskaniu pełnego wyjaśnienia dotyczącego zaistniałego stanu, powinni mieć możliwość odbycia kon- sultacji psychologicznej i podjęcia dalszej terapii. Trzeba pamiętać, że nowoczesnym działaniom chirurgicznym, jakim jest wszczepianie coraz bardziej zaawansowanych technologicznie urządzeń ICD, musi towarzyszyć działanie pełne empatii, zrozumienia i zaangażowania czasowego wobec chorych. Tylko takie komplementarne postępowanie przyczyni się do pełnego sukcesu zastosowanej terapii.

\section{Konflikt interesów}

Autorzy deklarują brak konfliktu interesów.

\section{Abstract}

The implantable cardioverter-defibrillators (ICD) have become the method of choice for the prevention of sudden cardiac death (SCD) since its approval by the Food and Drug Administration in 1985. Studies have shown that the use of ICD significantly increases the effectiveness of preventing SCD and reduces side effects compared with pharmacotherapy. In connection with the extension of the indications for implantation ICD in primary prevention by the European Society of Cardiology in 2001, significantly increased the number of people with this device. The lives of patients with ICD are changing and many people (up to $87 \%$ ) feel the anxiety associated with the working of the device. Studies have shown that predisposing factors for mental disorders occurring after implantation of the ICD are: patients younger than 50 years, female sex, lack of social and family support and numerous discharge devices. Patients should be aware of the working of ICD and participate in the therapies and support groups to help them control negative emotions, i.e. fear, anxiety and stress associated with the implanted device. Keep in mind that full therapeutic success after ICD implantation also depends on the patient's psychological well-being.

Key words: implantable cardioverter-defibrillator, anxiety, mental disorders, ICD discharge, stress

(Folia Cardiologica 2015; 10, 5: 342-347)

\section{Piśmiennictwo}

1. Bardy G.H., Lee K.L., Mark D.B. i wsp. Amiodarone or an implantable cardioverter-defibrillator for congestive heart failure. N. Engl. J. Med. 2005; 352: 225-237.

2. Moss A.J., Hall W.J., Cannom D.S i wsp. Improved survival with an implanted defibrillator in patients with coronary disease at high risk for ventricular arrhythmia. Multicenter Automatic Defibrillator Implantation Trial Investigators. N. Engl. J. Med. 1996; 335: 1933-1940.

3. Goldberger J.J. Treatment and prevention of sudden cardiac death: effect of recent clinical trials. Arch. Intern. Med. 1999; 159: 1281$-1287$.

4. Sears S., Conti J.B. Understanding implantable cardioverter defibrillator shocks and storms: medical and psychosocial considerations for research and clinical care. Clin. Cardiol. 2003; 26: 107-111.

5. Sears S,. Conti J.B. Quality of life and psychosocial functioning of ICD patients. Heart 2002; 87: 488-493.

6. Carroll D.L., Hamilton G.A., McGovern B.A. i wsp. Changes in health status and quality of life and the impact of uncertainty in patients who survive life-threatening arrhythmias. Heart Lung. 1999; 28: 251-260.

7. Ahmad M., Bloomstein L., Roelke M. i wsp. Patients' attitudes toward implanted defibrillator shocks. Pacing Clin. Electrophysiol. 2000; 23: 934-938.
8. Schron E.B., Exner D.V., Yao Q. i wsp. Quality of life in the antiarrhythmics versus implantable defibrillators trial: impact of therapy and influence of adverse symptoms and defibrillator shocks. Circulation 2002; 105: 589-594.

9. Zipes D.P., Roberts D. Results of the international study of the implantable pacemaker cardioverter- defibrillator: a comparison of epicardial and endocardial lead systems. The Pacemaker-Cardioverter-Defibrillator Investigators. Circulation 1995; 92: 59-65.

10. Credner S.C., Klingenheben T., Mauss 0. i wsp. Electrical storm in patients with transvenous implantable cardioverter-defibrillators: incidence, management and prognostic implications. J. Am. Coll. Cardiol. 1998; 32: 1909-1915.

11. Korte T., Jung W., Ostermann G. i wsp. Hospital readmission in patients with modern implantable cardioverter/defibrillator. Pacing Clin. Electrophysiol. 1997; 20: 1207.

12. O'Donoghue S., Platia E.V., Waclawski S. i wsp. Transient electrical storm: Prognostic significance of very numerous automatic defibrillator discharges. J. Am. Coll. Cardiol. 1991; 17: 352A.

13. Sweeney M.O., Wathen M.S., Volosin K. i wsp. Appropriate and inappropriate ventricular therapies, quality of life, and mortality among primary and secondary prevention implantable cardioverter defibrilla- 
tor patients: results from the Pacing Fast VT REduces Shock ThErapies (PainFREE Rx II) trial. Circulation 2005; 111: 2898-2905.

14. Daubert J.P., Zareba W., Cannom D.S. i wsp.; MADIT II Investigators. Inappropriate implantable cardioverter defibrillator shocks in MADIT II: frequency, mechanisms, predictors, and survival impact. J. Am. Coll. Cardiol. 2008; 51: 1357-1365.

15. van Rees J.B., Borleffs C.J., de Bie M.K. i wsp. Inappropriate implantable cardioverter defibrillator shocks: incidence, predictors, and impact on mortality. J. Am. Coll. Cardiol. 2011; 57: 556-562.

16. Maryniak A., Szumowski L., Walczak F. i wsp. Zespół stresu pourazowego u pacjenta z licznymi wyładowaniami ICD. Rola ablacji. Kardiol. Pol. 2006; 64: 910-912.

17. Sears S.F., Torado J.F., Saia T.L. i wsp. Examining the psychosocial impact of implantable cardioverter defibrillators: a literature review. Clin. Cardiol. 1999; 22: 481-489.

18. Kochańska A., Zarzycka B. Pacjent z implantowanym kardiowerterem-defibrylatorem serca (ICD). Czy można się przyzwyczaić do wyładowań kardiowertera-defibrylatora? Forum Med. Rodz. 2010; 4: 10-16.

19. Godemann F., Ahrens B., Behrens S. i wsp. Classic conditioning and dysfunctional cognitions in patients with panic disorder and agoraphobia treated with an implantable cardioverter defibrillator. Psychosom. Med. 2001; 63: 231-238.

20. Dunbar S.B., Langberg J.J., Reilly C.M. i wsp. Effect of a psychoeducational intervention on depression, anxiety, and health resource use in implantable cardioverter defibrillator patients. Pacing Clin. Electrophysiol. 2009; 14: 1259-1271.

21. Undavia M., Goldstein N.E., Cohen P. i wsp. Impact of implantable cardioverter-defibrillator recalls on patients' anxiety, depression, and quality of life. Pacing Clin. Electrophysiol. 2008; 31: 1411-1418.

22. Sears S.F., Burns J.L., Handberg E. i wsp. Young at heart: understanding the unique psychosocial adjustment of young implantable cardioverter defibrillator recipients. Pacing Clin. Electrophysiol. 2001; 24: 1113-1117.

23. Fricchione G.L., Olson L.C., Vlay S.C. Psychiatric syndromes in patients with the automatic internal cardioverter defibrillator: anxiety, psychological dependence, abuse, and withdrawal. Am. Heart J. 1989; 117: 1411-1414.

24. Łobodda K., Werner B., Kucińska B. Zaburzenia emocjonalne u chłopca z wszczepionym kardiowerterem-defibrylatorem. Pediatr. Pol. 2012; 87: 314-317.

25. Starrenburg A.H., Kraaier K., Pedersen S.S. i wsp. Association of psychiatric history and type $D$ personality with symptoms of anxiety, depression, and health status prior to ICD implantation. Int. J. Behav. Med. 2013; 20: 425-433.

26. Pedersen S.S., Theuns D.A., Muskens-Heemskerk A. i wsp. Type-D personality but not implantable cardioverter defibrillator indication is associated with impaired health-related quality of life 3 months post-implantation. Europace 2007; 9: 675-680.

27. Godemann F., Butter C., Lampe F. i wsp. Determinants of the quality of life (QoL) in patients with an implantable cardioverter/defibrillator (ICD). Qual. Life Res. 2004; 13: 411-416.

28. Simson U., Perings C., Plaskuda A. i wsp. Impact of attachment style, social support and the number of implantable cardioverter defibrillator (ICD) discharges on psychological strain of ICD patients. Psychother. Psychosom. Med. Psychol. 2006; 56: 493-499.
29. Thylen I., Dekker R.L., Jaarsma T. i wsp. Characteristics associated with anxiety, depressive symptoms, and quality-of-life in a large cohort of implantable cardioverter defibrillator recipients. J. Psychosom. Res. 2014; 77: 122-127.

30. Irvine J., Dorian P., Baker B. i wsp. Quality of life in the Canadian Implantable Defibrillator Study (CIDS). Am. Heart J. 2002; 144: 282-289.

31. Kohn C.S., Petrucci R.J., Baessler C. i wsp. The effect of psychological intervention on patients' long-term adjustment to the ICD: a prospective study. Pacing Clin. Electrophysiol. 2000; 23: 450-456.

32. Wallace R.L., Sears S.F., Lewis T.S. i wsp. Predictors of quality of life in long-term recipients of implantable cardioverter defibrillators. J. Cardiopulm. Rehabil. 2002; 22: 278-281.

33. Sears S.F., Eads A., Marhefka S. i wsp. The U.S. national survey of ICD recipients: examining the global and specific aspects of quality of life. Eur. Heart J. 1999; 20: 232.

34. Bilge A.K., Ozben B., Demircan S. i wsp. Depression and anxiety status of patients with implantable cardioverter defibrillator and precipitating factors. Pacing Clin. Electrophysiol. 2006; 29: 619-626.

35. Groeneveld P.W., Matta M.A., Suh J.J. i wsp. Quality of life among implantable cardioverter-defibrillator recipients in the primary prevention therapeutic era. Pacing Clin. Electrophysiol. 2007; 30: 463-471.

36. Pedersen S.S., Theuns D.A., Muskens-Heemskerk A. i wsp. Type-D personality but not implantable cardioverter defibrillator indication is associated with impaired health-related quality of life 3 months post-implantation. Europace 2007; 9: 675-680.

37. Pedersen S.S., Theuns D.A., Erdman R.A. i wsp. Clustering of device-related concerns and type $D$ personality predicts increased distress in ICD patients independent of shocks. Pacing Clin. Electrophysiol. 2008; 31: 20-27.

38. Van den Broek K.C., Nyklicek I., Van der Voort P.H. i wsp. Shocks, personality, and anxiety in patients with an implantable defibrillator. Pacing Clin. Electrophysiol. 2008; 31: 850- 857.

39. Van den Broek K.C., Nyklicek I., Denollet J. Anxiety predicts poor perceived health in patients with an implantable defibrillator. Psychosomatics 2009; 50: 483-492.

40. Vitale M.B., Funk M. Quality of life in younger persons with an implantable cardioverter defibrillator. Dimens. Crit. Care Nurs. 1995; 14: 100-111.

41. Walker R.L., Campbell K.A., Sears S.F. i wsp. Women and the implantable cardioverter defibrillator: a lifespan perspective on key psychosocial issues. Clin. Cardiol. 2004; 27: 543-546.

42. Dunbar S.B., Jenkins L.S., Hawthorne M. i wsp. Factors associated with outcomes 3 months after implantable cardioverter defibrillator insertion. Heart Lung. 1999; 28: 303-315.

43. Craney J.M., Mandle C.L., Munro B.H. i wsp. Implantable cardioverter defibrillators: physical and psychosocial outcomes. Am. J. Crit. Care 1997; 6: 445-451.

44. Burns J., Serber E., Keim S. i wsp. Measuring patient acceptance of implantable cardiac device therapy: initial psychometric investigation of the Florida Patient Acceptance Survey. J. Cardiovasc. Electrophysiol. 2005; 16: 384-390.

45. Namerow P.B., Firth B.R., Heywood G.M. i wsp. Quality of life six months after $C A B G$ surgery in patients randomized to ICD versus no ICD therapy: findings from the CABG Patch Trial. Pacing Clin. Electrophysiol. 1999; 22: 1305-1313. 